\title{
Influence of heat treatment on the microstructure of synthetic nodular cast irons
}

Alan Vaško

Department of Materials Engineering, Faculty of Mechanical Engineering, University of Žilina, Univerzitná 8215/1, 01026 Žilina, Slovak Republic, alan.vasko@fstroj.uniza.sk

The article deals with the influence of charge composition on the microstructure and mechanical properties of synthetic nodular cast irons after casting and after heat treatment (ferritizing annealing and isothermal heat treatment). The paper shows a comparison of the microstructure of nodular cast irons with the graded amount of steel scrap in a charge. The chemical composition of individual meltages was regulated alternatively by ferrosilicon (FeSi) and carburizer or metallurgical silicon carbide (SiC). The results of the experiments show that the SiC additive positively influences the microstructure as well as the mechanical properties of nodular cast iron, especially in specimens from the meltages with a higher ratio of steel scrap in the charge. Moreover, the production of synthetic nodular cast irons with a $\mathrm{SiC}$ additive is economically advantageous.

Keywords: nodular cast iron, ferritizing annealing, isothermal heat treatment, silicon carbide

\section{Acknowledgements}

Author is grateful for the support of experimental works by grant projects VEGA No. 1/0460/11 and No. 1/0841/11.

\section{References}

[1] GERHARDT, R. (2011). Properties and applications of silicon carbide, 536 p. InTech, Rijeka, Croatia.

[2] MUKHERJEE, M. (2011). Silicon carbide - materials, processing and applications in electronic devices, 546 p. InTech, Rijeka, Croatia.

[3] SCHUBERT, W. D., TA, A. T., KAHR, G., BENECKE, T., LUX, B. (1984). Influence of SiC additions on the microstructure of gray cast iron. In: Physical metallurgy of cast iron, pp. 119-128. Stockholm, Sweden.

[4] ONSOIEN, M. I., SKALAND, T. (2001). Preconditioning of gray iron melts using ferrosilicon or silicon carbide, Transactions of the American Foundry Society, p. 1-12.

[5] VENKATESWARAN, S., WILFING, J., SCHUBERT, W. D., LUX, B., BENECKE, T. (1989). Influence of SiC and FeSi additions on the microstructure, cooling curve and shrinkage porosity of ductile iron. In: Physical metallurgy of cast iron, pp. 171-178. Tokyo, Japan.

[6] VAŠKO, A. (2008). Influence of $\mathrm{SiC}$ additive on microstructure and mechanical properties of nodular cast iron. Materials science (Medžiagotyra), Vol. 14, No. 4, pp. 311-314.

[7] WARDA, R. (1998). Ductile iron data for design engineers, Rio Tinto Iron \& Titanium, Montreal, Canada.

[8] KARSAY, S. I. (1996). Ductile iron I. Production, pp. 199, Fompex, Trenčín.

[9] GEDEONOVÁ, Z., JELČ, I. (2000). Iron castings metallurgy, pp. 288. HF TU, Košice.

[10] SKOČOVSKÝ, P., ŠIMAN, I. (1989). Structural analysis of iron castings, pp. 256. ALFA, Bratislava.

[11] SKOČOVSKÝ, P., VAŠKO, A. (2007). Quantitative evaluation of iron casting structure, 73 p. EDIS, Žilina.

[12] BELAN, J. (2008). Structural analyses of advanced material for aerospace industry. Materials science (Medžiagotyra), Vol. 14, No. 4, pp. 315-318.

[13] TILLOVÁ, E., CHALUPOVÁ, M., HURTALOVÁ, L., ĎURINíKOVÁ, E. (2011). Quality control of microstructure in recycled Al-Si cast alloys. Manufacturing Technology, Vol. 11, No. 11, pp. 70-76.

[14] ĎURINÍKOVÁ, E., TILLOVÁ, E. (2011). Phase and structure characteristics of recycled AlZn10Si8Mg cast alloy. Manufacturing Technology, Vol. 11, No. 11, pp. 11-17.

[15] VAŠKO, A., SKOČOVSKÝ, P. (2009). Properties and means of use of materials, 96 p. EDIS, Žilina.

[16] SÁGA, M., KOPAS, P., VAŠKO, M. (2010). Some computational aspects of vehicle shell frames optimization subjected to fatigue life. Communications, Vol. 12, No. 4, pp. 73-79.

[17] DORAZIL, E. (1985). High-strength bainitic ductile iron, pp. 176. Academia, Praha.

[18] SKOČOVSKÝ, P., PODRÁBSKÝ, T. (2005). Graphite cast iron, 168 p. EDIS, Žilina.

[19] SKOČOVSKÝ, P., BOKƯVKA, O., KONEČNÁ, R., TILLOVÁ, E. (2006). Material science for departments of mechanical engineering, 349 p. EDIS, Žilina. 